\title{
SPECTRAL AND ECOLOGICAL Characterization OF Yellowstone LODGEPOLE PINE COVER TYPES
}

\author{
MARK E. JAKUBAUSKAS $\bullet$ KEVIN P. PRICE \\ KANSAS APPLIED REMOTE SENSING (KARS) PROGRAM \\ AND DEPARTMENT OF GEOGRAPHY \\ UNIVERSITY OF KANSAS • LAWRENCE
}

\section{$\checkmark \quad$ INTRODUCTION}

Accurate mapping of forest successional stages, or cover types, is critical for fire behavior prediction, animal habitat management, and preservation of biodiversity. Two research projects were based at the UW/NPS Research Station during the 1993 summer field season. The first project is a continuation of work begun in 1992, in which Landsat Thematic Mapper multispectral data are being used to identify the spectral reflectance characteristics of Yellowstone lodgepole pine cover types, and examine the relationships between spectral and biotic factors. A second project to characterize interception of photosynthetically active radiation (PAR) in lodgepole pine cover types using a portable integrating radiometer was initiated in 1993, but poor field conditions limited the number of samples that were taken.

\section{$\checkmark \quad$ STUd AREA}

Projects were carried out in the Central Plateau region of Yellowstone. Despain (1990) classifies the vegetation of the Yellowstone Central Plateau into the subalpine fir/grouse whortleberry Abies lasiocarpa/Vaccinium Scoparium habitat type, consisting of lodgepole pine forest in a mosaic of successional stages. Romme (1982) identified six postfire successional stages as occurring within the region: 1) herbaceous stage, 0 - 20 years; 2) seedling/sapling stage, 20-40 years; 3), immature pine forest, 40-150 years; 4), mature pine forest, 150-200/300 years; 5), transitional forest, 200/300 $300 / 400$ years; , and 6), the climax forest, which on xeric sites consists of lodgepole pine $(300+$ years), and on more mesic sites, subalpine fir $(400+$ years $)$.

\section{$\checkmark \quad$ METHODS}

Methods used for pre-field analysis of Geographic Information System (GIS) and Thematic Mapper (TM) data are described in detail in Jakubauskas and Price (1993, 1994), and briefly summarized as follows. Ten spectrally distinct forest cover type classes were created from analysis of the multispectral TM data, using a GIS to restrict analysis to areas that were relatively flat (slope $<3$ percent), between $2200 \mathrm{~m}$ and $2600 \mathrm{~m}$ in elevation, and on the Pinedale Till and Rubble surficial geology types. In the field, environmental factors were measured at 70 sample plots located within polygons of the spectral classes derived from the satellite and GIS data analysis. Live and dead trees were tallied by species in 16 size classes within $20 \mathrm{~m} \times 25 \mathrm{~m}$ sample plots. Visual estimates of understory cover were recorded using the Daubenmire technique (Daubenmire, 1959) within twenty $0.5 \mathrm{~m} \times 0.5 \mathrm{~m}$ understory quadrats established at equal intervals along four transects (five quadrats/transect). 
Canopy transmittance of PAR was measured in forest stands in late June 1993 on cloudless days between 1000 and 1400 local solar time, using a Sunfleck Ceptometer (model SF-70, Decagon Devices, Inc.). Environmental characteristics of the stands were measured as part of the fieldwork performed in 1992 . Within each stand, two $100 \mathrm{~m}$ transects were established perpendicular to each other, intersecting at the center of the stand. Measurements of PAR were taken at $5 \mathrm{~m}$ intervals along each transect. At each point, 20 measurements were taken while turning in a $360^{\circ}$ circle and the 20 measurements were then averaged to obtain mean PAR for the point (Pierce and Running, 1988). Calibration readings of total incoming PAR were taken in sunlit clearings at the start and end of each transect. Due to poor sampling conditions (cloudy days), only eight stands were sampled in 1993.

\section{POST-FIELD DATA PROCESSING}

Overstory density (overstory trees/ha), seedling density (seedlings/ha), number of seedlings by species, dead density (standing dead trees/ha), and basal area were computed from size-class data collected for each stand (4 tree species and standing dead x 16 diameter classes). All data were normalized to a one-hectare standard unit. Basal area for living and dead trees was computed using the mean diameter value for each size class (e.g., $2.5 \mathrm{~cm}$ for the $0-5 \mathrm{~cm}$ size class). Biomass for living overstory species was computed using the allometric equations from Gholz et al. (1979). Leaf area index (LAI) was computed for each stand using the basal area equations of Kaufman et al. (1982). Total percent living cover, and percent cover by life form (e.g., shrubs, grasses, and forbs) was computed for each plot. For each site, mean spectral values for each TM band were computed from a $3 \times 3$ pixel block centered on the site. Measurements of PAR for each site were downloaded to a computer and converted to fraction of total incoming PAR using the calibration readings for each transect.

\section{DATA ANALYSIS}

Sites sampled in 1992 and 1993 were classified into seven lodgepole pine cover types using criteria derived in part from Romme (1982) and Despain (1977). The classification scheme follows that of Romme (1982) in that it divides Despain's LP0 stage into two cover types, but differs by including a separate class (LPi) for insect-affected stands. Correlation analysis was used to explore the relationships between forest stand parameters and spectral reflectance, and examine how attributes common to all forest stands affect spectral reflectance.

\section{$\checkmark \quad$ RESUlts \\ SPECTRAL CHARACTERISTICS OF COVER TYPES}

Changes in reflectance between cover types are shown in Figure 1. Decreases in spectral reflectance are rapid in the visible (TM 1,2, and 3) and middle-infrared (TM 5 and 7) bands during the initial stages of stand regeneration (LPOa to LPOb), but the rate of change decreases as the stand progresses into later stages (LP2 and LP3). The visible bands change at a similar rate, but TM 3 shows a greater differentiation between LP3 and LP sites. LP sites are brighter than LP3 sites in all bands except TM 4, where LP sites are much darker. TM 4 shows a sharp increase between the two LPO classes. TM 4 provides the best distinction between LP3 and LP sites of the six TM bands. LPi stands exhibit high reflectance in all TM bands except band 4 , and are most spectrally similar to LPOb stands.

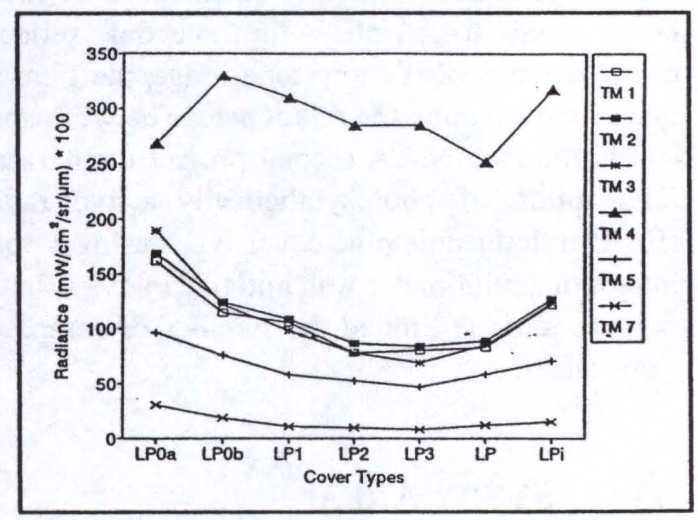

Figure 1. Landsat Thematic Mapper (TM) spectral reflectance changes for lodgepole pine cover types.

\section{OVERSTORY RELATIONSHIPS WITH SPECTRAL DATA}

TM spectral response in all bands except TM band 4 is negatively correlated with age, height, 
mean tree diameter, frequency of overstory species, size diversity, basal area, lodgepole biomass, total plot biomass, and total leaf area index (LAI) (Table 1). These biotic factors are linked to the successional state of a site, increasing with age and stand development. Spectral response was related positively to the number of lodgepole pine seedlings, which were most abundant in early succession. Conversely, a negative relationship was noted between TM spectral response and the seedling frequency of subalpine fir and whitebark pine, which are both more abundant in older stands.

\section{CANOPY INTERCEPTION OF PAR}

The number of stands sampled for the PAR project was insufficient for statistical analysis, but general trends of canopy light interception may be inferred from the data available. Patterns of canopy light interception for early successional (LP1, 126 years) and late successional (LP, 335 years) forest stands are strikingly different (Figure 2). The dense overstory of the LP1 stand allows little penetration of light to the forest understory, with a mean percent canopy transmittance of $0.23 \%$ (Table 2). Canopy gaps are numerous but small, indicated by the low standard deviation (s.d. $=0.08$ ). In contrast, canopy gaps in the LP stand are fewer in number but larger in size, allowing a greater fraction of total incoming PAR to penetrate to the forest floor (mean percent canopy transmittance $=0.47 \%$, s.d. $=0.24$ ).

Table 1

Correlations between environmental and TM spectral variables

$\begin{array}{llllll}\text { TM } 1 & \text { TM } 2 & \text { TM } 3 & \text { TM } 4 & \text { TM } 5 & \text { TM } 7\end{array}$

\section{OVERSTORY FACTORS}

Age (years since establishment)

$\log _{10}$ Age

Height of the dominants (m)

Mean tree diameter $(\mathrm{cm})$

Living density (trees/ha)

Overstory density (trees/ha)

Number of species (no.)

Size diversity

Basal area ( $\left.\mathrm{m}^{2} / \mathrm{ha}\right)$

Percent seedlings (\%)

Number of seedlings (seedl./ha)

Lodgepole pine seedlings (seedl./ha)

Whitebark pine seedlings (seedl./ha)

Subalpine fir seedlings (seedl./ha)

Dead density (trees/ha)

Dead basal area $\left(\mathrm{m}^{2} / \mathrm{ha}\right)$

Percent dead (\%)

Lodgepole pine biomass ( $\mathrm{kg} / \mathrm{ha}$ )

Whitebark pine biomass ( $\mathrm{kg} / \mathrm{ha})$

Subalpine fir biomass $(\mathrm{kg} / \mathrm{ha})$

Total plot biomass $(\mathrm{kg} / \mathrm{ha})$

Total LAI $\left(\mathrm{m}^{2} / \mathrm{m}^{2}\right)$

$\begin{array}{rrrrrr}-0.65 & -0.64 & -0.59 & -0.29 & -0.51 & -0.53 \\ -0.78 & -0.78 & -0.80 & & -0.74 & -0.84 \\ -0.81 & -0.80 & -0.81 & & -0.77 & -0.83 \\ -0.72 & -0.68 & -0.67 & & -0.58 & -0.63 \\ 0.50 & 0.49 & 0.49 & & 0.49 & 0.43 \\ & & & & & \\ & -0.24 & -0.32 & 0.30 & -0.39 & -0.45 \\ -0.56 & -0.53 & -0.50 & & -0.44 & -0.41 \\ -0.61 & -0.60 & -0.58 & & -0.53 & -0.59 \\ -0.75 & -0.74 & -0.76 & & -0.76 & -0.77 \\ 0.41 & 0.42 & 0.48 & & 0.54 & 0.55 \\ & & & & & \\ 0.51 & 0.50 & 0.53 & & 0.54 & 0.50 \\ 0.54 & 0.54 & 0.56 & & 0.56 & 0.52 \\ -0.42 & -0.40 & -0.37 & & -0.29 & -0.28 \\ -0.25 & -0.25 & -0.25 & & -0.31 & -0.23 \\ 0.28 & 0.24 & & & & \\ & & & & & \\ 0.27 & & 0.27 & -0.49 & 0.35 & 0.49 \\ & & & & & \\ -0.66 & -0.65 & -0.68 & & -0.68 & -0.70\end{array}$

$\begin{array}{lllll}-0.73 & -0.72 & -0.75 & -0.76 & -0.76 \\ -0.76 & -0.75 & -0.78 & -0.78 & -0.77\end{array}$

All correlations significant at the $p \leq 0.05$ level using the two-tailed test. 


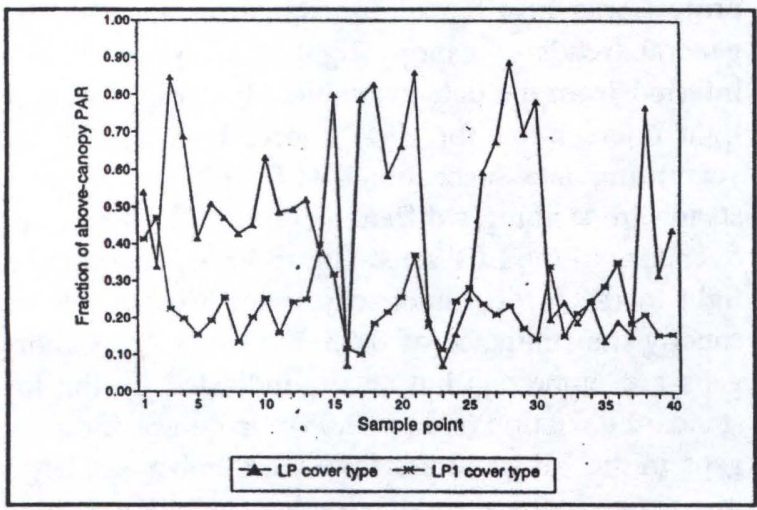

Figure 2. Plot of canopy transmittance (fraction of above-canopy PAR) for early successional (LP1) and late successional (LP) lodgepole pine cover types.

Table 2. Characteristics of two sites sampled for fraction of total above canopy PAR.

\begin{tabular}{|c|c|c|}
\hline Cover type & LP1 & LP \\
\hline Mean canopy PAR transmittance ( & (\%Q.23 & 0.47 \\
\hline $\begin{array}{l}\text { Standard deviation of } \\
\text { canopy PAR transmittance }\end{array}$ & 0.08 & 0.24 \\
\hline Age (years) & 126 & 335 \\
\hline Height (m) & 12.75 & 21.75 \\
\hline Mean DBH $(\mathrm{cm})$ & 8.94 & 19.35 \\
\hline Overstory live density (trees/ha) & 5900 & 920 \\
\hline Size diversity & 0.31 & 0.81 \\
\hline Live basal area $\left(\mathrm{m}^{2} / \mathrm{ha}\right)$ & 40.60 & 39.25 \\
\hline Total seedlings (no.) & 200 & 7660 \\
\hline Overstory dead density (trees/ha) & 2900 & 120 \\
\hline Dead basal area $\left(\mathrm{m}^{2} / \mathrm{ha}\right)$ & 8.10 & 4.54 \\
\hline Total biomass (kg/ha) & 461.23 & 7650.96 \\
\hline Total LAI $\left(\mathrm{m}^{2} / \mathrm{m}^{2}\right)$ & 7.064 & 6.830 \\
\hline TM 1 (radiance, $\left.\mathrm{mW} / \mathrm{cm}^{2} / \mathrm{sr} / \mu \mathrm{m}\right)$ & 115.56 & 90.89 \\
\hline TM 2 (radiance, $\left.\mathrm{mW} / \mathrm{cm}^{2} / \mathrm{sr} / \mu \mathrm{m}\right)$ & 117.89 & 97.00 \\
\hline TM 3 (radiance, $\left.\mathrm{mW} / \mathrm{cm}^{2} / \mathrm{sr} / \mu \mathrm{m}\right)$ & 107.22 & 95.44 \\
\hline TM $4\left(\operatorname{radiance}, \mathrm{mW} / \mathrm{cm}^{2} / \mathrm{sr} / \mu \mathrm{m}\right)$ & 288.44 & 262.00 \\
\hline TM 5 (radiance, $\left.\mathrm{mW} / \mathrm{cm}^{2} / \mathrm{sr} / \mu \mathrm{m}\right)$ & 56.56 & 62.78 \\
\hline TM 7 (radiance, $\left.\mathrm{mW} / \mathrm{cm}^{2} / \mathrm{sr} / \mu \mathrm{m}\right)$ & 11.11 & 13.33 \\
\hline NDVI (index value) & 464.56 & 466.00 \\
\hline
\end{tabular}

\section{$\checkmark \quad$ ACKNOWLEDGEMENTS}

This research was supported by a National Aeronautics and Space Administration Global Climate Change Fellowship and a grant from the University of Wyoming/National Parks Service Research Center. We thank Todd Sutphin and Clayton Blodgett for assistance in the field, and Jerry Whistler, Clayton Blodgett, and Terry Slocum for technical advice and assistance.

\section{LITERATURE CITED}

Daubenmire, R. 1959. A canopy-coverage method of vegetational analysis. Northwest Science 33:43-66.

Despain, D.G. 1977. Forest successional stages in Yellowstone National Park. Information Paper No. 32, Yellowstone National Park, National Park Service.

Despain, D.G. 1990. Yellowstone Vegetation: Consequences of Environment and History in a Natural Setting. Roberts Rinehart, Boulder, Colorado.

Gholz, H.L., Grier, C.C., Campbell, A.G., and Brown, A.T. 1979. Equations for estimating biomass and leaf area of plants in the Pacific Northwest. Research Paper 41, Forest Research Laboratory, School of Forestry, Oregon State University, Corvallis, Oregon.

Jakubauskas, M.E., and Price, K.P. 1993. Spectral-ecological characterization and mapping of forest habitat and cover types within Yellowstone National Park, Wyoming. 16th Annual Report, University of Wyoming/National Park Service Research Center, G.E. Plumb and H.J. Harlow, eds., pp 184-187.

Jakubauskas, M.E., and Price, K.P. 1994. Landsat Thematic Mapper Characterization of Coniferous Forest Succession. Proceedings of the 1994 American Society for Photogrammetry and Remote Sensing Annual Meeting, Reno, Nevada.

Kaufmann, M.R., Edminster, C.B, and Troendle, C.A. 1982. Leaf Area Determinations for Subalpine Tree Species in the Central Rocky Mountains. Rocky Mountain Forest and Range Experiment Station Research Paper RM-238. US Forest Service, Department of Agriculture. 
Pierce, L.L., and Running, S.W. 1988. Rapid estimation of coniferous leaf area index using a portable integrating radiometer. Ecology 69(6):1762-1767.
Romme, W.H. 1982. Fire and landscape diversity in subalpine forests of Yellowstone National Park. Ecological Monographs 52(2):199221. 